\title{
Recovery of rainbow trout (Oncorhynchus mykiss) after subchronic nitrite exposure
}

\author{
Eliška Zusková, Jana Máchová, Josef Velíšek, Alžběta Stará, Zdeňka Svobodová, \\ Hana Kocour Kroupová
}

University of South Bohemia in České Budějovice, Faculty of Fisheries and Protection of Waters, South Bohemian Research Center of Aquaculture and Biodiversity of Hydrocenoses, Research Institute of Fish Culture and Hydrobiology, Vodňany, Czech Republic

Received April 23, 2012

Accepted October 23, 2012

\begin{abstract}
The aim of the study was to assess the effect of elevated nitrite concentration on the haematological and biochemical profile of blood of rainbow trout and to evaluate the ability of fish to recover under varying conditions. Fish $(n=72)$ were exposed for 14 days to elevated nitrite concentration $\left(1 \mathrm{mg} \cdot 1^{-1}\right)$. Thereafter the exposed fish were divided into four groups and monitored for 7 days in the following conditions: water containing $1 \mathrm{mg} \cdot \mathrm{l}^{-1} \mathrm{NO}_{2}$ (group E), water containing $1 \mathrm{mg} \cdot l^{-1} \mathrm{NO}_{2}^{-}+100 \mathrm{mg} \cdot l^{-1} \mathrm{Cl}^{-}$(group R1), nitrite-free water with $100 \mathrm{mg} \cdot \mathrm{l}^{-1} \mathrm{Cl}^{-}$(group R2), or nitrite- and chloride-free water (group R3). Nitrite exposure was associated with a significant increase $(P<0.01)$ in methaemoglobin, mean corpuscular haemoglobin and plasma nitrite concentration. During the subsequent 7 days these indices reached the control values in all recovery groups $(\mathrm{R} 1-\mathrm{R} 3)$. Significant decrease $(P<0.01)$ in haematocrit and mean corpuscular volume was recorded during nitrite exposure of fish. These changes were eliminated by addition of chloride to the water. Other haematological and biochemical blood indices showed that all treatments resulted in moderate stress to fish with the least pronounced changes in group R1. Results of the present study confirmed that even low nitrite concentrations may cause physiological changes in rainbow trout and pointed to possible recovery treatments of fish impaired by nitrite exposure. One of the most important findings is that chloride added to the water leads to successful fish recovery even in the presence of nitrite.
\end{abstract}

Fish, haematology, methaemoglobin, nitrite accumulation, blood biochemistry

Nitrite is potentially toxic to animals, and fish are at a higher risk than terrestrial animals, since nitrite in the ambient water can be actively taken up across the gill epithelium and accumulate at high concentrations in the body fluids. Nitrite has an affinity for the branchial $\mathrm{Cl}^{-}$uptake mechanisms, presumably the $\mathrm{Cl}^{-} / \mathrm{HCO}_{3}^{-}$exchange (Jensen 2003), which takes place in the chloride cells of gill epithelium. Williams and Eddy (1988) demonstrated that fish with high chloride uptake across chloride cells (e.g. rainbow trout) are more sensitive to nitrite than fish with a low rate of chloride intake (e.g. carp, tench). This explains the protective effect of chloride on nitrite toxicity.

The toxic effect of nitrite as well as its influence on physiological function in fish is well documented (Jensen 2003; Kroupová et al. 2005; Voslarova et al. 2006, 2008; Dolezalova et al. 2011). Nitrite affects the regulation of ions in fish tissue, respiration, cardiovascular function, endocrine function, and excretory mechanisms (Jensen 2003). However, the chief outcome of nitrite poisoning is the oxidation of haemoglobin to methaemoglobin in erythrocytes. Consequently, blood oxygen transport is compromised, since methaemoglobin does not bind oxygen.

The aim of the present study was to assess the effects of elevated nitrite concentrations on the haematological and blood biochemical profiles of rainbow trout and to evaluate the ability of fish to recover under varying conditions. 


\section{Materials and Methods}

Experimental animals

The total of 100 rainbow trout $(72.3 \pm 14.0 \mathrm{~g})$ was obtained from a local hatchery and maintained for 1 week in aquaria with dechlorinated tap water. Fish were fed a commercial diet (BioMar, $47 \%$ protein, $26 \%$ fat) daily at $2.5 \%$ of total body weight. Four fish were examined for their health status before the start of experiment.

Water quality indices were: temperature $14.3-15.2{ }^{\circ} \mathrm{C}$; dissolved oxygen $>68 \%, \mathrm{pH} 7.2-7.9$, acid neutralisation capacity $\left(\mathrm{ANC}_{4.5}\right) 1.2 \mathrm{mmol} \cdot \mathrm{l}^{-1}$, chemical oxygen demand $\left(\mathrm{COD}_{\mathrm{Mn}}\right) 1.5 \mathrm{mg} \cdot \mathrm{l}^{-1}$, total ammonia $0.04 \mathrm{mg} \cdot \mathrm{l}^{-1}$, sum of $\mathrm{Ca}^{2+}+\mathrm{Mg}^{2+} 14 \mathrm{mg} \cdot \mathrm{l}^{-1}, \mathrm{Cl}^{-1} 11 \mathrm{mg} \cdot \mathrm{l}^{-1}$, and $\mathrm{PO}_{4}{ }^{3-} 0.01 \mathrm{mg} \cdot \mathrm{l}^{-1}$.

Toxicity test protocol

A prolonged toxicity test was carried out using a modified test design of OECD Direction No. 204 Fish, Prolonged Toxicity Test and ISO 10229 (2007) - Water Quality. Fish were exposed to $1 \mathrm{mg} \cdot \mathrm{l}^{-1} \mathrm{NO}_{2}^{-}$, a concentration that commonly occurs in intensive aquaculture systems. The desired concentration was obtained by addition of sodium nitrite. A chloride concentration of $100 \mathrm{mg} \cdot \mathrm{l}^{-1}$ was obtained by addition of sodium chloride. Nitrite and chloride concentrations were checked daily during the test, and measured values did not differ from those stated for test purposes by more than $10 \%$. The test baths had constant aeration. Oxygen saturation, $\mathrm{pH}$, and temperature were measured daily.

\section{Experimental protocol}

Forty-eight fish were divided into two groups (control and experimental). Control and experimental group consisted of 12 and 36 fish, respectively. The supply water and diet used were the same as those during the initial acclimation period. The bath was renewed daily. During the 14 days exposure period, experimental fish $(\mathrm{n}=36)$ were exposed to $1 \mathrm{mg} \cdot \mathrm{l}^{-1} \mathrm{NO}_{2}$ and controls $(\mathrm{n}=12)$ were maintained in nitrite-free tap water.

At the end of the exposure period, four experimental and four control fish were sampled. Group E continued to be exposed to $1 \mathrm{mg} \cdot 1^{-1} \mathrm{NO}_{2}^{-}$and the remaining fish from the experimental group were divided into 3 groups (R1-R3) to evaluate recovery from nitrite poisoning. Water treatments following initial exposure to nitrite were: water containing $1 \mathrm{mg} \cdot \mathrm{l}^{-1} \mathrm{NO}_{2}^{-}+100 \mathrm{mg} \cdot l^{-1} \mathrm{Cl}^{-}$(group R1); nitrite-free water with $100 \mathrm{mg} \cdot \mathrm{l}^{-1} \mathrm{Cl}^{-}$(group R2); nitritefree tapwater (group R3). This post-exposure period continued for 7 days, with sampling of 4 fish per group on day 2 and at the conclusion of the test. Entire experiment was done in duplicate. The experimental system is shown in Fig. 1.

\section{Fish sampling}

Blood samples were taken from the caudal vessels into heparinised syringes, and the blood was stabilised with $40 \mathrm{IU}$ of sodium heparin (Heparin inj., Leciva, Czech Republic) per $1 \mathrm{ml}$ blood. Immediately after sampling, the erythrocyte count (RBC), haematocrit (PCV), haemoglobin ( $\mathrm{Hb})$, methaemoglobin (MetHb), mean corpuscular volume (MCV), mean corpuscular haemoglobin $(\mathrm{MCH})$, mean corpuscular haemoglobin concentration (MCHC), and leukocyte count (WBC) were determined according Svobodová et al. (1991).

Plasma was separated from cells by centrifugation $(10 \mathrm{~min}$ at $12000 \times g)$ at $4{ }^{\circ} \mathrm{C}$, and plasma ammonia $\left(\mathrm{NH}_{3}\right)$, urea nitrogen (UREA), uric acid (URIC), glucose (Glu), total protein (TP), albumin (ALB), total globulin (Glob), calcium $\left(\mathrm{Ca}^{2+}\right)$, magnesium $\left(\mathrm{Mg}^{2+}\right)$, and inorganic phosphorus concentrations (PHOS) were determined using the VETTEST 8008 Analyser (IDEXX Laboratories, Westbrook, ME, USA). Plasma $\mathrm{Na}^{+}, \mathrm{K}^{+}$, and $\mathrm{Cl}^{-}$concentrations were measured with an automated clinical chemistry analyser, Radiometer ABL90 FLEX.

After blood sampling, the fish were quickly stunned with a blow to the head, and dorsal muscle samples of approximately $1 \mathrm{~g}$ were excised. The muscle and plasma samples for nitrite determination were kept at

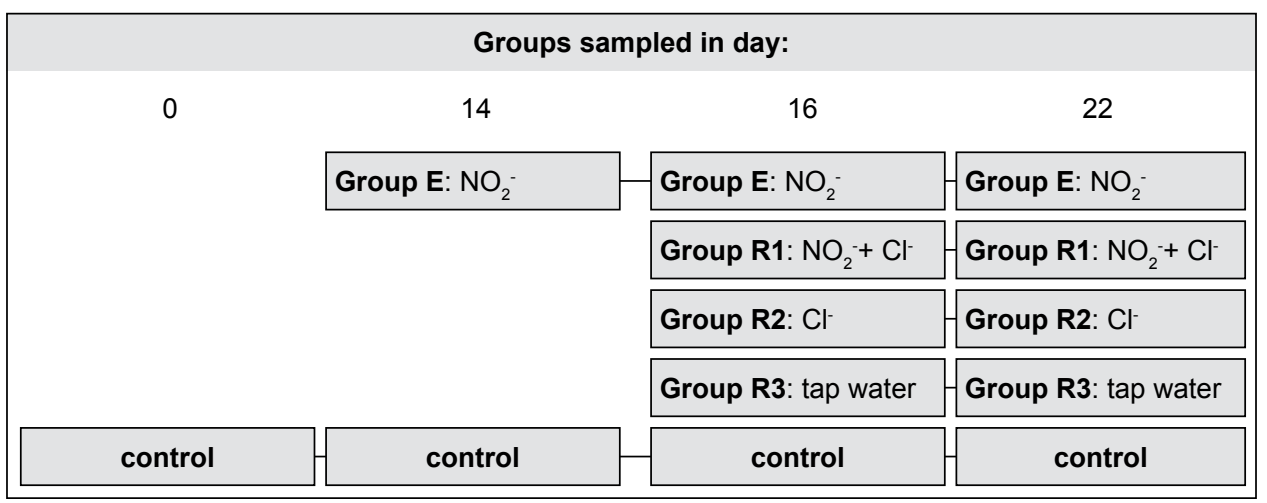

Fig. 1. The experimental design - each group consisted of four fish. 
$-80^{\circ} \mathrm{C}$ until time of analysis to prevent nitrite oxidation. Nitrite levels in the plasma and muscle were determined spectrophotometrically as described by Shechter et al. (1972).

Statistical analyses

Statistical analysis was carried out with Statistica software 7.0 for Windows (StatSoft, Czech Republic). Data were first tested for normality (Kolmogorov-Smirnov test) and homoscedasticity of variance (Bartlett's test). Where those conditions were satisfied, two-way analysis of variance (ANOVA) was employed to determine whether there were significant differences in measured variables among experimental groups. When a difference was detected $(P<0.05)$, Tukey's multiple comparison test was applied to identify which treatments were significantly different.
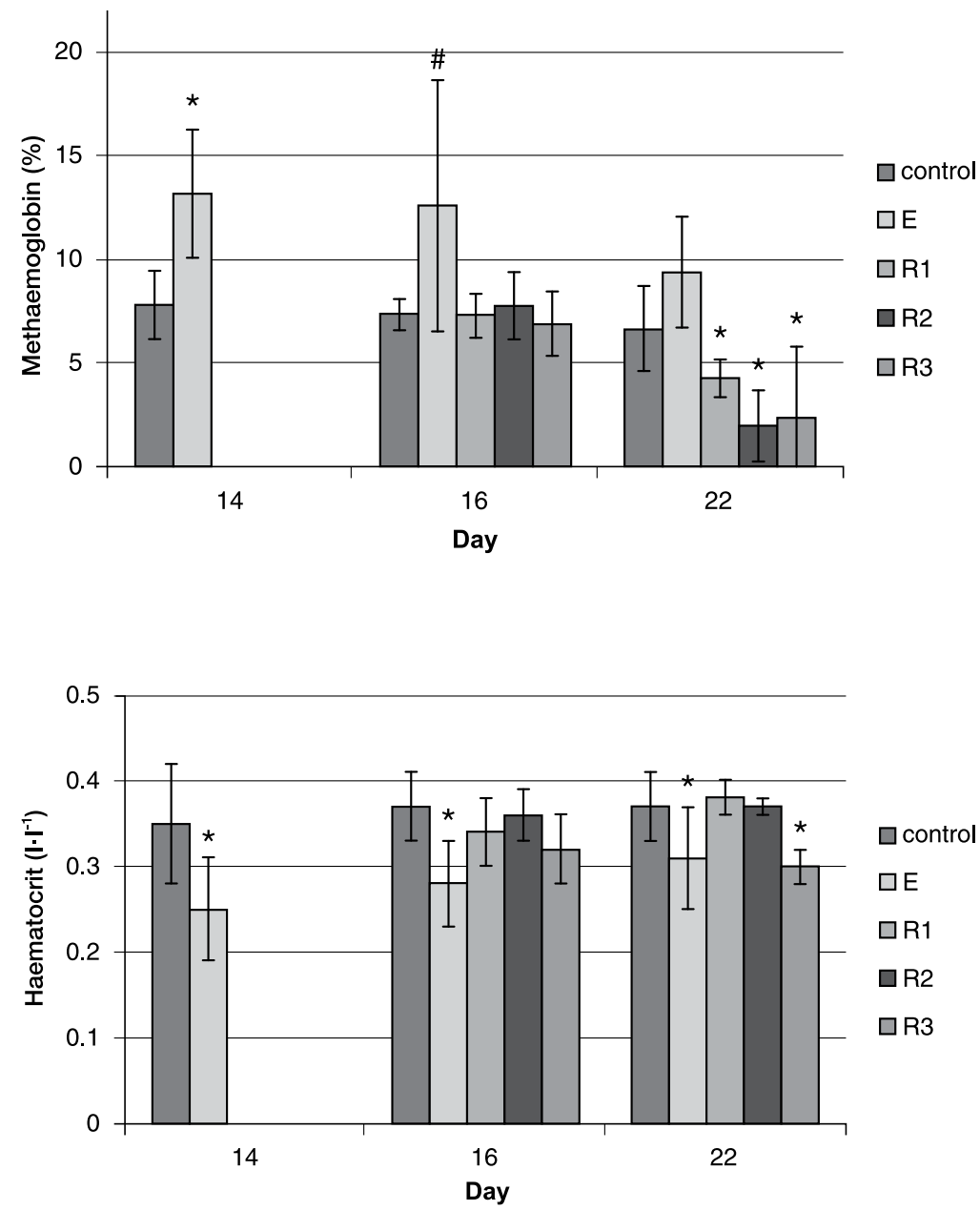

Fig. 2. Haematological indices of rainbow trout after 14 days exposure to nitrite and during recovery period (day 16 and 22).

Experimental groups E $\left(1 \mathrm{mg} \cdot l^{-1} \mathrm{NO}_{2}^{-}\right), \mathrm{R} 1\left(1 \mathrm{mg} \cdot \mathrm{l}^{-1} \mathrm{NO}_{2}^{-}+100 \mathrm{mg} \cdot \mathrm{l}^{-1} \mathrm{Cl}^{-}\right), \mathrm{R} 2\left(100 \mathrm{mg} \cdot \mathrm{l}^{-1} \mathrm{Cl}^{-}\right), \mathrm{R} 3$ (nitrite-and chloride free tap water) and control group. *Experimental groups significantly different $(P<0.01)$ from control group. \#Experimental group significantly different $(P<0.05)$ from control group. 


\section{Results}

Significant differences among experimental groups were observed in the MetHb and PCV values following exposure. MetHb content increased markedly $(P<0.01)$ in group E after 14-day exposure compared to control. During the subsequent 7 days this indicator gradually declined. The most significant decrease in MetHb content $(P<0.01)$ was observed in groups R2 and R3 at the end of trial, day 22 (Fig. 2).

The PCV values were significantly lower $(P<0.01)$ in group $\mathrm{E}$ sampled on days 14 , 16 , and 22 compared to the time-corresponding controls. Lower PCV values were also

Table 1. Haematological indices of rainbow trout after 14 days nitrite exposure and during recovery period (days 16 and 22).

\begin{tabular}{lcccccc}
\hline \multicolumn{7}{c}{ Group } \\
\hline Indices & $\begin{array}{c}\text { Sample time } \\
\text { (days) }\end{array}$ & $\begin{array}{c}\text { Control } \\
\text { mean } \pm \text { SD }\end{array}$ & $\begin{array}{c}\text { E } \\
\text { mean } \pm \text { SD }\end{array}$ & $\begin{array}{c}\text { R2 } \\
\text { mean } \pm \text { SD }\end{array}$ & $\begin{array}{c}\text { R3 } \\
\text { mean } \pm \text { SD }\end{array}$ & $\begin{array}{c}\text { R4 } \\
\text { mean } \pm \text { SD }\end{array}$ \\
\hline \multirow{2}{*}{ MCV (fl) } & 14 & $332.8 \pm 52.4^{\mathrm{a}}$ & $247.2 \pm 67.8^{\mathrm{b}}$ & - & - & - \\
& 16 & $343.9 \pm 43.2^{\mathrm{a}}$ & $265.2 \pm 53.2^{\mathrm{b}}$ & $277.0 \pm 30.9^{\mathrm{b}}$ & $364.3 \pm 37.6^{\mathrm{a}}$ & $313.6 \pm 43.6^{\mathrm{ab}}$ \\
& 22 & $325.5 \pm 20.32^{\mathrm{ab}}$ & $273.9 \pm 79.9^{\mathrm{a}}$ & $355.9 \pm 34.8^{\mathrm{b}}$ & $325.7 \pm 38.1^{\mathrm{ab}}$ & $305.5 \pm 36.5^{\mathrm{ab}}$ \\
& 14 & $0.18 \pm 0.03^{\mathrm{a}}$ & $0.21 \pm 0.05^{\mathrm{a}}$ & - & - & - \\
MCHC $\left(11^{-1}\right)$ & 16 & $0.16 \pm 0.02^{\mathrm{a}}$ & $0.19 \pm 0.03^{\mathrm{b}}$ & $0.16 \pm 0.01^{\mathrm{a}}$ & $0.15 \pm 0.01^{\mathrm{a}}$ & $0.16 \pm 0.02^{\mathrm{ab}}$ \\
& 22 & $0.16 \pm 0.02^{\mathrm{a}}$ & $0.20 \pm 0.05^{\mathrm{b}}$ & $0.16 \pm 0.01^{\mathrm{ab}}$ & $0.17 \pm 0.01^{\mathrm{ab}}$ & $0.18 \pm 0.02^{\mathrm{ab}}$ \\
\hline
\end{tabular}

Experimental groups E $\left(1 \mathrm{mg} \cdot \mathrm{l}^{-1} \mathrm{NO}_{2}^{-}\right), \mathrm{R} 1\left(1 \mathrm{mg} \cdot \mathrm{l}^{-1} \mathrm{NO}_{2}^{-}+100 \mathrm{mg} \cdot \mathrm{l}^{-1} \mathrm{Cl}^{-}\right), \mathrm{R} 2\left(100 \mathrm{mg} \cdot \mathrm{l}^{-1} \mathrm{Cl}^{-}\right), \mathrm{R} 3$ (nitritefree tapwater) and control group. MCV - mean corpuscular volume, $\mathrm{MCHC}$ - mean corpuscular haemoglobin

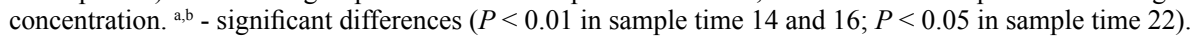

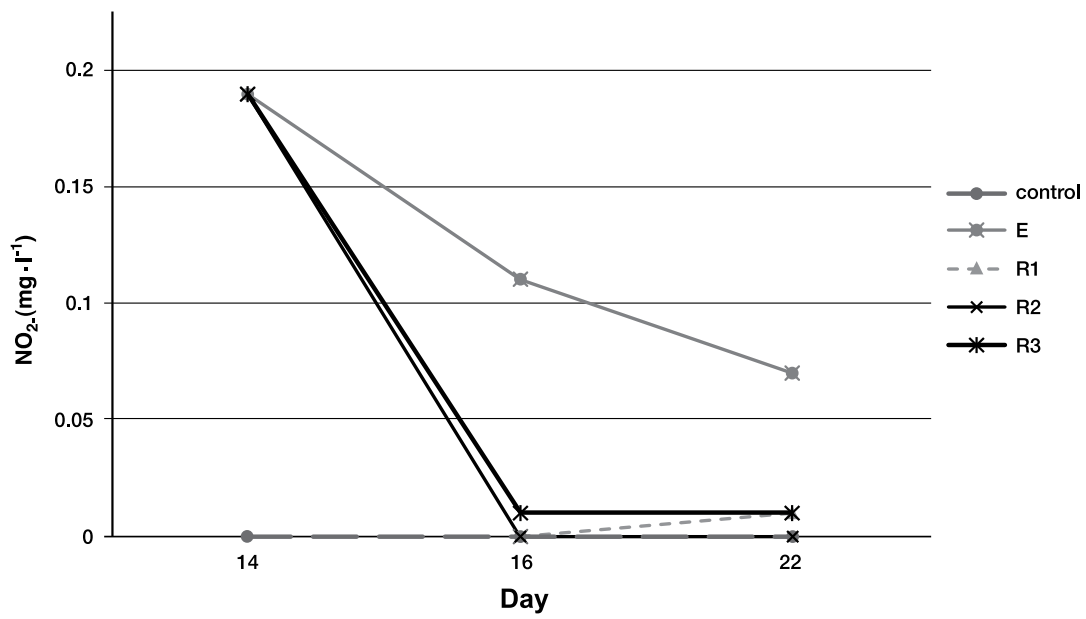

Fig. 3. Nitrite concentration in the plasma of rainbow trout after 14 days exposure to nitrite and during recovery period (day 16 and 22).

Experimental groups E $\left(1 \mathrm{mg} \cdot l^{-1} \mathrm{NO}_{2}^{-}\right), \mathrm{R} 1\left(1 \mathrm{mg} \cdot \mathrm{l}^{-1} \mathrm{NO}_{2}^{-}+100 \mathrm{mg} \cdot \mathrm{l}^{-1} \mathrm{Cl}^{-}\right), \mathrm{R} 2\left(100 \mathrm{mg} \cdot \mathrm{l}^{-1} \mathrm{Cl}^{-}\right), \mathrm{R} 3$ (nitrite-and chloride- free tap water) and control group. Group $\mathrm{E}$ is significantly different $(P<0.05)$ from control group in each sample time. 
Table 2. Biochemical indices of rainbow trout after 14 days exposure to nitrite and during the recovery period (days 16 and 22).

\begin{tabular}{lcccccc}
\hline \multicolumn{7}{c}{ Group } \\
\hline Indices & $\begin{array}{c}\text { Sample time } \\
(\text { days })\end{array}$ & $\begin{array}{c}\text { Control } \\
\text { mean } \pm \mathrm{SD}\end{array}$ & $\begin{array}{c}\mathrm{E} \\
\text { mean } \pm \mathrm{SD}\end{array}$ & $\begin{array}{c}\mathrm{R} 1 \\
\text { mean } \pm \mathrm{SD}\end{array}$ & $\begin{array}{c}\mathrm{R} 2 \\
\text { mean } \pm \mathrm{SD}\end{array}$ & $\begin{array}{c}\mathrm{R} 3 \\
\text { mean } \pm \mathrm{SD}\end{array}$ \\
\hline \multirow{3}{*}{ Glu $\left(\mathrm{mmol} \cdot \mathrm{l}^{-1}\right)$} & 14 & $5.40 \pm 0.80^{\mathrm{a}}$ & $4.94 \pm 1.04^{\mathrm{a}}$ & - & - & - \\
& 16 & $3.60 \pm 0.72^{\mathrm{a}}$ & $3.96 \pm 0.41^{\mathrm{ab}}$ & $4.69 \pm 0.26^{\mathrm{b}}$ & $4.81 \pm 0.41^{\mathrm{b}}$ & $4.70 \pm 0.30^{\mathrm{b}}$ \\
& 22 & $5.57 \pm 0.33^{\mathrm{a}}$ & $5.24 \pm 0.55^{\mathrm{a}}$ & $5.78 \pm 0.79^{\mathrm{ab}}$ & $6.49 \pm 0.36^{\mathrm{b}}$ & $5.58 \pm 0.26^{\mathrm{a}}$ \\
\hline \multirow{3}{*}{ PHOS $\left(\mathrm{mmol} \cdot \mathrm{l}^{-1}\right)$} & 14 & $3.76 \pm 0.24^{\mathrm{a}}$ & $3.17 \pm 0.60^{\mathrm{a}}$ & - & - & - \\
& 16 & $4.17 \pm 0.40^{\mathrm{a}}$ & $3.97 \pm 0.28^{\mathrm{a}}$ & $3.93 \pm 0.22^{\mathrm{a}}$ & $3.45 \pm 0.15^{\mathrm{b}}$ & $3.54 \pm 0.17^{\mathrm{b}}$ \\
& 22 & $4.40 \pm 0.35^{\mathrm{ab}}$ & $4.62 \pm 0.27^{\mathrm{ab}}$ & $4.41 \pm 0.18^{\mathrm{ab}}$ & $4.81 \pm 0.30^{\mathrm{b}}$ & $4.25 \pm 0.14^{\mathrm{a}}$ \\
\hline \multirow{3}{*}{$\mathrm{NH}_{3}\left(\mu \mathrm{mol} \cdot \mathrm{l}^{-1}\right)$} & 14 & $794 \pm 139^{\mathrm{a}}$ & $573 \pm 126^{\mathrm{b}}$ & - & - & - \\
& 16 & $1042 \pm 139^{\mathrm{a}}$ & $863 \pm 153^{\mathrm{a}}$ & $904 \pm 136^{\mathrm{a}}$ & $625 \pm 56^{\mathrm{b}}$ & $471 \pm 77^{\mathrm{b}}$ \\
& 22 & $1061 \pm 120^{\mathrm{a}}$ & $1048 \pm 89^{\mathrm{a}}$ & $1083 \pm 122^{\mathrm{a}}$ & $1191 \pm 117^{\mathrm{a}}$ & $738 \pm 62^{\mathrm{b}}$ \\
\hline \multirow{2}{*}{$\mathrm{UREA}\left(\mathrm{mmol} \cdot \mathrm{l}^{-1}\right)$} & 14 & $0.53 \pm 0.05^{\mathrm{a}}$ & $0.55 \pm 0.10^{\mathrm{a}}$ & - & - & - \\
& 16 & $0.67 \pm 0.05^{\mathrm{a}}$ & $0.63 \pm 0.08^{\mathrm{a}}$ & $0.65 \pm 0.08^{\mathrm{a}}$ & $0.57 \pm 0.05^{\mathrm{a}}$ & $0.48 \pm 1.17^{\mathrm{b}}$ \\
& 22 & $0.63 \pm 0.08^{\mathrm{a}}$ & $0.68 \pm 0.08^{\mathrm{a}}$ & $0.60 \pm 0.09^{\mathrm{ab}}$ & $0.65 \pm 0.05^{\mathrm{a}}$ & $0.48 \pm 0.04^{\mathrm{b}}$ \\
\hline
\end{tabular}

Experimental groups E (1 $\left.\mathrm{mg} \mathrm{l}^{-1} \mathrm{NO}_{2}^{-}\right), \mathrm{R} 1\left(1 \mathrm{mg} \mathrm{l}^{-1} \mathrm{NO}_{2}^{-}+100 \mathrm{mg} \mathrm{l}^{-1} \mathrm{Cl}^{-}\right), \mathrm{R} 2\left(100 \mathrm{mg} \mathrm{l}^{-1} \mathrm{Cl}^{-}\right), \mathrm{R} 3$ (nitrite-free tapwater) and the control group. Glu - glucose concentration, PHOS - inorganic phosphorus concentrations, $\mathrm{NH}_{3}$ - plasma ammonia concentration, UREA - urea nitrogen concentration.

a,b - significant differences $(P<0.01)$.

detected in group R3 on days 16 and 22 compared to the control group; however, the changes were significant $(P<0.01)$ only at day 22 (Fig. 2 ).

Other haematological indicators such as MCV and MCHC in groups R1-3, reached control values by the second day of the post-exposure period (day 16), while the difference in these indices between group $\mathrm{E}$ and the control group persisted to the end of the experiment (day 22) - see Table 1.

Elevated nitrite was found in the plasma of fish of group E sampled on days 14, 16, and 22 compared with the time-corresponding controls (Fig. 3). Nitrite concentration in plasma decreased slightly during the experimental period in this group. In groups R1-3, and in the controls the values were below the detection threshold for the method used $\left(0.05 \mathrm{mg} \cdot \mathrm{l}^{-1} \mathrm{NO}_{2}^{-}\right)$at all sampled times. Nitrite in muscle was below the detection threshold in all groups.

Significant differences in Glu, PHOS, $\mathrm{NH}_{3}$ and UREA in plasma were observed on day 2 of the post-exposure period in groups R1-3 compared to the control group. Glu significantly increased $(P<0.01)$ in groups R1-3 and remained significantly higher in group R2 throughout the trial. The values of PHOS and $\mathrm{NH}_{3}$ were significantly lower $(P<0.01)$ in groups R 2 and 3 on day 2 of the post-exposure period. PHOS reached control values at the end of the experiment in all groups. The values of $\mathrm{NH}_{3}$ remained significantly lower $(P<0.01)$ in group R3 throughout the experiment. The UREA level was significantly lower in group R3 on day 2 of the post-exposure period and remained significantly lower $(P<0.01)$ in this group until the end of experiment (Table 2$)$.

\section{Discussion}

The most prominent effect of nitrite poisoning in fish is the increase in methaemoglobin content. Methaemoglobinaemia usually results from exposure to 
high concentrations of nitrite, although a small amount of methaemoglobin can be formed spontaneously in normal erythrocytes in the absence of nitrite (Svobodová et al. 2005). Smith and Russo (1975) established the values of $0.9-3.6 \%$ as the normal methaemoglobin-haemoglobin equilibrium for rainbow trout, Oncorhynchus mykiss (Walbaum). As expected, exposure of rainbow trout to nitrite in the present study caused a significant increase in methaemoglobin concentrations. However, the measured values of methaemoglobin were relatively low, ranging from 8 to $13 \%$, and continuously declined in fish exposed to nitrite during the experiment. This suggested acclimation of the exposed fish to elevated nitrite concentrations in the water, probably due to increased activity of the methaemoglobin-reductase system. Avilez et al. (2004) measured increased activity of methaemoglobin-reductase in Brycon cephalus after 96- h exposure to several nitrite concentrations, supporting our hypothesis that the enzyme system may be activated by nitrite presence in water as well as by the duration of exposure. In experimental groups R1-3 fish recovery after nitrite exposure was observed, and methaemoglobin reached control values on day 2 of the recovery period and continued declining below control values until the end of the experiment. This suggested adequate and comparable efficacy of all the three treatment conditions: nitrite containing water supplemented with chloride (R1), nitrite-free water supplemented with chloride (R2), and nitrite-free water with no supplementation (R3).

Nitrite exposed fish with no change in treatment (group E) showed lower PCV values at all sampling times compared to controls. While PCV and MCV decreased in group E, RBC and $\mathrm{Hb}$ remained unchanged. In this case, a decrease in PCV might be explained by red blood cell shrinkage, as reported by Jensen et al. (1987). This hypothesis is supported by an increase in MCHC, which may be elevated by erythrocyte shrinkage. Similar changes in PCV were observed in group R3 on days 16 and 22. Erythrocyte cell membranes generally show little channel activity, but they are permeable to $\mathrm{Cl}^{-}$. Osmotic cell shrinkage, however, opens non-selective cation channels in the erythrocyte cell membrane (Huber et al. 2001). Thus erythrocyte shrinkage is connected with disruption of ion equilibrium resulting in the osmotically driven flow of water out of the cells. Huber et al. (2001) described the ability of intracellular or extracellular $\mathrm{Cl}^{-}$to inhibit the permeability of these channels. This is in accordance with our observation of a positive effect of chloride addition to the water on haematocrit stabilisation after nitrite exposure.

Elevated nitrite concentrations were found in the plasma of fish exposed to $1.0 \mathrm{mg} \cdot \mathrm{l}^{-1}$ $\mathrm{NO}_{2}{ }^{-}$at all sampling times compared to controls, but we found no measurable concentration in muscle. The plasma concentrations of nitrite observed in our experiment are similar to results obtained by Kroupová et al. (2008). In the present study, the gradually decreasing concentration of plasma nitrite during the recovery period (group E) suggested acclimation of rainbow trout to nitrite with long-term exposure.

It has been shown that nitrite may have some general effect on nitrogen metabolism and excretion (Jensen 2003). We detected reduced plasma ammonia and urea nitrogen in groups R2 and R3. These changes could be associated with the elevation in glucose concentration. One result of stress-related hyperglycaemia is a decrease in food intake, and this could subsequently lead to decreased intensity of nitrogen metabolism. This hypothesis is supported by the changes in inorganic phosphorus concentration, as one of the major determinants of plasma phosphorus concentration is dietary intake as along with gastrointestinal absorption (Marks et al. 2010).

Results of the present study confirmed that even low nitrite concentrations may cause physiological changes in rainbow trout and pointed to possible treatments for fish impaired by nitrite exposure. One of the most important findings is that chloride added to the water leads to successful fish recovery even in the presence of nitrite. These 
results suggest that in aquaculture recirculation systems, in which fish are exposed to enhanced nitrite concentrations, the impact of nitrite can be reduced by chloride supplementation to negatively influence the process of nitrification without radical water exchange.

\section{Acknowledgments}

This research was supported by the centre CENAQUA no. CZ.1.05/2.1.00/01.0024, Project USB (GAJU), no. 047/2010/Z, Project NAZV QH 82117 and Project GACR, no. P503/10/P492.

\section{References}

Avilez IM, Altran AE, Aguiar LH, Moraes G 2004: Hematological responses of the Neotropical teleost matrinxa (Brycon cephalus) to environmental nitrite. Comp Biochem Phys C 139: 135-139

Dolezalova P, Macova S, Pistekova V, Svobodova Z, Bedanova I, Voslarova E 2011: Nitrite toxicity assessment in Danio rerio and Poecilia reticulata. Acta Vet Brno 80: 309-312

Huber SM, Gamper N, Lang F 2001: Chloride conductance and volume-regulatory nonselective cation conductance in human red blood cell ghosts. Pflugers Arch 441: 551-558

ISO 10229 2007: Water quality - Determination of the prolonged toxicity of substances to freshwater fish Method for evaluating the effects of substances on the growth rate of rainbow trout (Oncorhynchus mykiss Walbaum (Teleostei, Salmonidae))

Jensen FB 2003: Nitrite disrupts multiple physiological functions in aquatic animals. Comp Biochem Phys A 135: $9-24$

Kroupová H, Máchová J, Piačková V, Blahová J, Dobšíková R, Novotný L, Svobodová Z 2008: Effects of subchronic nitrite exposure on rainbow trout (Oncorhynchus mykiss). Ecotox Environ Safe 71: 813-820

Kroupová H, Máchová J, Svobodová Z 2005: Nitrite influence on fish - a review. Vet Med - Czech 50: 461-471

Marks J, Debnam ES, Unwin RJ 2010: Phosphate homeostasis and the renal-gastrointestinal axis. Am J Physiol Ren Physiol 299: F285-F296

Shechter H, Gruener N, Shubal HI 1972: Micromethod for the determination of nitrite in blood. Analytica Chimica Acta 60: 93-99

Smith CE, Russo RC 1975: Nitrite-induced methemoglobinemia in rainbow trout. Prog Fish Cult 37: 150-152

Svobodová Z, Máchová J, Drastichová J, Groch L, Lusková V, Poleszczuk G, Velíšek J, Kroupová H 2005: Haematological and biochemical profile of carp blood following nitrite exposure at different concentration of chloride. Aquacult Res 36: 1177-1184

Svobodová Z, Pravda D, Paláčková J 1991: Unified methods of haematological examination of fish. Methods No. 20, Research Institute of Fish Culture and Hydrobiology, Vodňany, Czech Republic, $31 \mathrm{p}$.

Voslarova E, Pistekova V, Svobodova Z 2006: Nitrite toxicity to Danio rerio: Effects of fish age and chloride concentrations. Acta Vet Brno 75: 107-113

Voslarova E, Pistekova V, Svobodova Z, Bedanova I 2008: Nitrite toxicity to Danio rerio: Effects of subchronic exposure on fish growth. Acta Vet Brno 77: 455-460

Williams EM, Eddy FB 1988: Anion transport, chloride cell number and nitrite-induced methaemoglobinaemia in rainbow trout (Salmo gairdneri) and carp (Cyprinus carpio). Aquat Toxicol 13: 29-42 